УДК 621.923.6:621.318.4:621.002.1

( Т. А. Роїк, д.т.н., професор, П. О. Киричок, д.т.н., професор, О. С. Хлус, аспірантка, А. П. Гавриш, д.т.н., професор, НТУУ «КПІ», Київ, Україна

\title{
ТЕМПЕРАТУРНЕ ПОЛЕ ПІДШИПНИКІВ КОВЗАННЯ ПОЛІГРАФІЧНИХ МАШИН \\ З ВИСОКОЗНОСОСТІЙКИХ КОМПОЗИТІВ \\ НА ОСНОВІ ІНСТРУМЕНТАЛЬНИХ СТАЛЕЙ I НІКЕЛЮ ЗА УМОВ ТОНКОГО АБРАЗИВНОГО ШЛІФУВАННЯ ПОВЕРХОНЬ ТЕРТЯ
}

У статті наведено результати теоретико-експериментального дослідження температурного поля підшипників ковзання поліграфічних машин з нових високозносостійких композиційних матеріалів, синтезованих на основі використання утилізованих та регенерованих відходів виробництва деталей з інструментальних сталей і нікелю типу 11РЗАМЗФ2,

7ХГ2ВМФ, 5ХВЗМФС, ХН55ВТКЮ, ХН50ВТФКЮ, та його впливу на формування залишкових напружень у поверхневому шарі композитної деталі для умов тонкого абразивного шліфування. Запропоновано чисельно-аналітичний метод вирішення задач термопружності і визначення температур-

ного поля структурно-неоднорідного тіла для випадку стабільності силових параметрів різання у зоні формування напружень за умов прецизійного тонкого абразивного шліфування. Запропонований метод базується на методі кінцевих елементів вирішення задач термопружності. Отримано залежності для визначення температурного поля i наведено числові приклади їх вирішення для реальних умов виробництва. Розроблено практичні рекомендації по режимам різання при тонкому шліфуванні та призначенню параметрів абразивних інструментів для промисловості при виробництві поліграфічних машин.

Ключові слова: високозносостійкі композиційні матеріали; тонке абразивне шліфування; параметри якості поверхні; температурне поле зони різання; термопружність; структурно-неоднорідне тіло; варіаційний функціонал; зародок тріщини; промислові рекомендації.

Постановка проблеми

Однією 3 найважливіших проблем при створенні новітніх зразків сучасної техніки для тех- нологічних комплексів є забезпечення високих параметрів їх надійності, довговічності, зносостійкості та ремонтоздатності.

(C) $2016 \mathrm{p}$. 


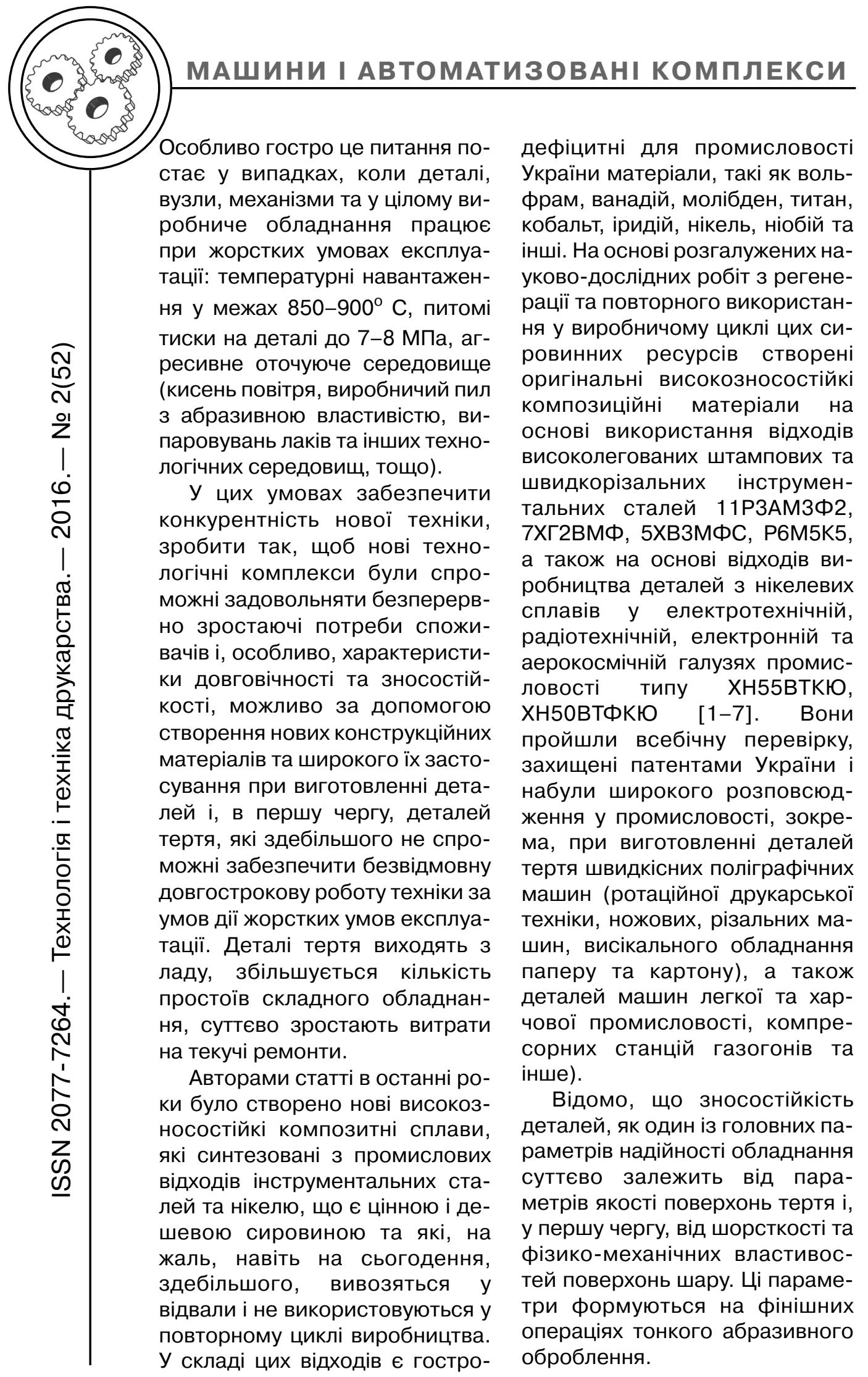


Незважаючи на те, що нові високозносостійкі композиційні матеріали на основі інструментальних сталей і нікелю були створені відносно нещодавно і набули широкого розповсюдження у промисловості в останні 10-15 років, науковцями на сьогодення отримані експериментально перевірені рекомендації для виробництва по широкому колу технологічних надтонких оздоблювальновикінчувальних процесів фінішного оброблення поверхонь деталей тертя поліграфічних машин. Детально досліджені технологічні процеси тонкого абразивного, алмазного, ельборового, кубонітового та боразонового шліфування, а також прецизійна машинна доводка плоских поверхонь, кінцево-оздоблювальне хонінгування прецизійних отворів та високопрецизійне суперфінішування зовнішніх циліндричних поверхонь деталей обертання [2, 4-7, 32-39]. Отримано залежності параметрів шорсткості поверхні $\mathrm{R}_{\mathrm{a}}$, ступеня наклепу $\mathrm{K}$ та глибини $\mathrm{h}$ його проникнення у тіло деталі від режимів різання, складу і структури абразивного інструменту, його зернистості, типу зв'язки, матеріалу зерна абразиву, а також від складу і типу мастильно-охолоджуючої рідини (MOP).

Класична теорія фрикційного зношування деталей тертя машин [2, 3, 6-19, 32-38], акцентує увагу на тому, що крім шорсткості поверхні та параметрів наклепу, на процес тертя і зношування суттєво впливають величина і знак залишкових напружень поверхневих шарів, що утворюються при зрізанні з поверхонь тертя тонких стружок поодиноким абразивним зерном інструменту і взаємодії при цьому складових сил різання і миттєвих контактних температур на ріжучому лезі абразивного зерна, що формують теплове поле у зоні оброблення.

На жаль, ці процеси до останнього часу недостатньо досліджені і, це, безумовно, впливає на розуміння фізичних процесів, що відбуваються у надтонких шарах деталей тертя, які працюють в умовах щільного контакту у відповідних вузлах і механізмах машин, а також не сприяє призначенню таких режимів абразивного оброблення, які могли б підвищити параметри довговічності і зносостійкості композитних деталей, що виготовлені 3 новітніх марок матеріалів, синтезованих 3 відходів інструментальних сталей і виготовлення деталей з нікелевих сплавів.

На жаль, є лише невелика кількість спроб розрахунків залишкових напружень у зоні дії температурних полів безпосередньо у місці їх виникнення на ріжучому лезі абразивного зерна (при зрізанні надтонких стружок з поверхонь композитних деталей) для умов надтонкого абразивного оброблення [2-4, $6,7,20-24,37-39]$. Отже, задача вивчення впливу теплового поля на напружений стан поверхневого шару підшипників ковзання, що виготовлені 3 новітніх високозносостійких композиційних матеріалів, за умов їх тонкого абразивного шліфування $€$ важливою технологічною проблемою, позитив- 


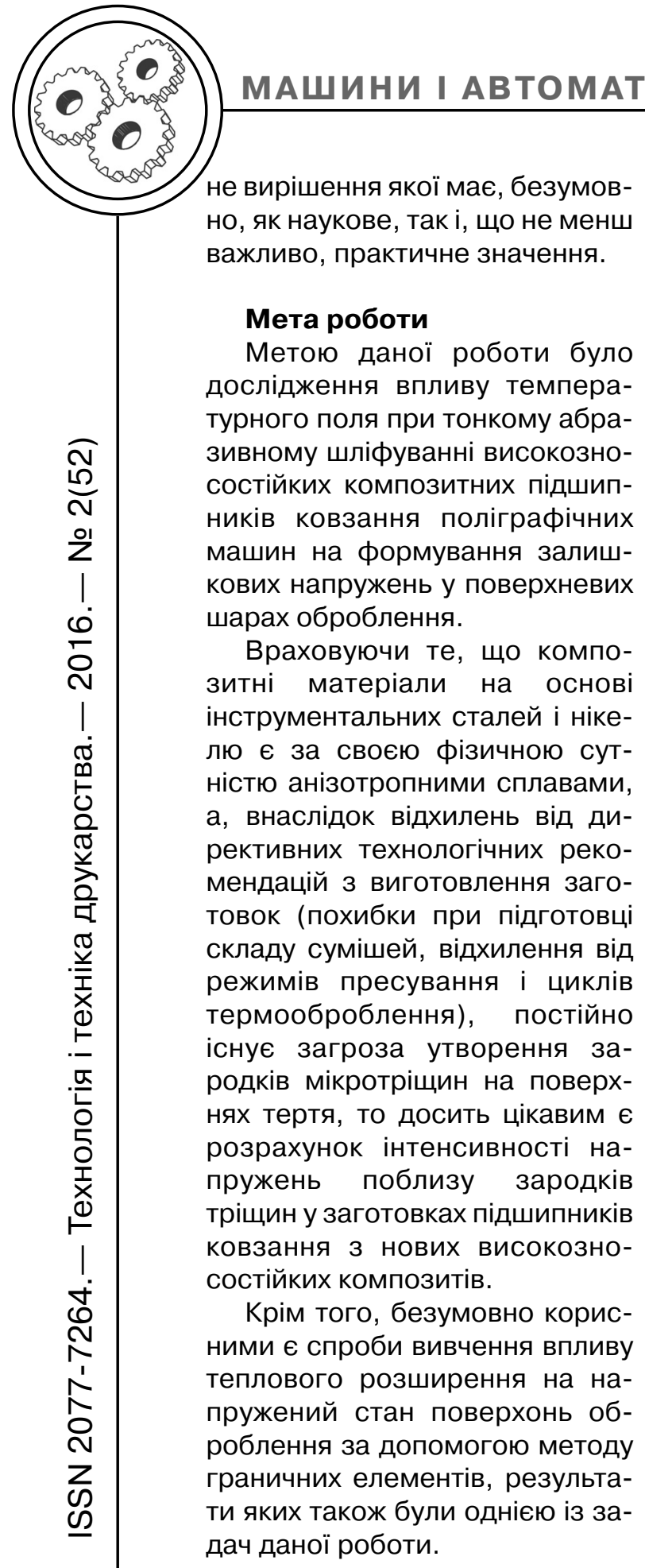

Результати проведених досліджень

Експериментальні дослідження виконувались на прецизійному шліфувальному вер- статі SS-125 фірми «Werkzojt» (ФРН) абразивними кругами 3 електрокорунда хромчастого 33АМ28СМ1Гл на еластичній гліфталевій зв'язці (Гл) із вмістом у складі абразиву до 1,8-2 \% оксиду хрома CrO. Усі досліди (у відповідності з рекомендаціями, наведеними у роботах [2, 4-7]) здійснені з наступними режимами різання - швидкість шліфувального кругу $\mathrm{V}_{\mathrm{kp}}=45 \mathrm{~m} / \mathrm{c}$, швидкість виробу $V_{\text {в }}=45$ об./хв., подача $S=20$ мм/хід, глибина різання $\mathrm{t}=0,020 \mathrm{~mm}$.

Дослідження виконувались на зразках 3 композитів на основі інструментальних сталей 7ХГ2ВМФ, 11РЗАМЗФ2, 5ХВЗМФС та відходів нікелевих сплавів ХН55ВМТКЮ і ХН50ВТФКЮ [1-7].

Розрахунки напружень здійснювались з використанням відомих математичних методів скінченних та граничних елементів [22, 23, 25-31]. До речі, у роботах [27, 30] ці методи успішно були застосовані до аналізу анізотропних тіл із зародками тріщин при їх механічному навантаженні.

Проте, при вивченні впливу теплового розширення на напружений стан тіл за допомогою методу граничних елементів (МГЕ), у числовій схемі слід обчислювати додатковий об'ємний інтеграл, що часто нівелює усі переваги МГЕ. У випадку ізотропного тіла цей об'ємний інтеграл можна перетворити до граничного. Саме такий спосіб було використано у роботах [28, 29] при дослідженнях термопружної рівноваги ізотропних тіл з зародками тріщин. Однак, у 
випадку анізотропних тіл, якими і $є$ новітні зносостійкі композити, що синтезовані на основі інструментальних сталей та відходів нікелевих сплавів зведення об'ємного інтегралу до поверхневого стає досить громіздким завданням. у роботі [21] для випадку неоднорідних ортотропних площин, півплощин та смуг задача термопружності зведена до інтегрального рівняння Вольтера [25-28]. Для вирішення задачі у випадку, який передбачає розбиття зайнятої тілом області на окремі ділянки, у кожній з яких температура апроксимується поліномом. У працях [29-31] запропоновано алгоритм перетворення об'ємного інтегралу до контурного. Цей підхід успішно використано при аналізі термонапруженого стану анізотропних тіл із зародками тріщин у робо$\operatorname{Tax}[30,31]$.

Тому у даній статті запропоновано напіваналітичний скінченноелементний підхід аналізу задач термопружності структурно неоднорідних тіл.

Загальна постановка задачі термопружності для неоднорідного ізотропного тіла у випадку, якщо деформації зумовлені лише змінами у часі температурного поля, тобто механічні навантаження стабільні, а саме це маємо при тонкому шліфуванні [21-31], полягає у наступному.

Необхідно визначити 16 функцій координат $x_{\text {к }}$ та часу, а саме: шість компонент тензору напружень $\sigma_{\mathrm{ij}}$, шість компонент тензору деформацій $\varepsilon_{\mathrm{ij}}$, три компоненти вектору переміщень $\mathrm{u}_{\mathrm{i}}$ та температуру T, що задовольняють умовам:

1) трьом рівнянням рівноваги $\sum \partial \sigma_{\mathrm{ij}} / \partial \mathrm{x}_{\mathrm{j}}=0$;

2) рівняння теплопровідності

$$
\begin{aligned}
& \frac{\partial}{\partial \mathrm{x}}\left(\lambda_{\mathrm{i}} \frac{\partial \mathrm{T}}{\partial \mathrm{x}}\right)+\frac{\partial}{\partial \mathrm{y}}\left(\lambda_{\mathrm{i}} \frac{\partial \mathrm{T}}{\partial \mathrm{y}}\right)+ \\
& +\frac{\partial}{\partial \mathrm{z}}\left(\lambda_{\mathrm{i}} \frac{\partial \mathrm{T}}{\partial \mathrm{z}}\right)=\mathrm{c} \rho \frac{\partial \mathrm{T}}{\partial \mathrm{t}},
\end{aligned}
$$

де $\lambda_{\mathrm{i}}-$ коефіцієнт теплопровідності тіла; с - питома теплоємність тіла; $\mathrm{C}=\mathrm{c} \rho-$ об'ємна теплоємність тіла.

3) шість співвідношень між напруженнями та деформаціями

$\sigma_{\mathrm{ij}}=2 \mu \varepsilon_{\mathrm{ij}}+\left[\lambda \varepsilon_{\mathrm{kk}}-(3 \lambda+2 \mu) \alpha_{\mathrm{T}}(\mathrm{T}-\right.$ $\left.\left.-\mathrm{T}_{0}\right) \delta_{\mathrm{il}}\right]$,

де $\alpha_{\mathrm{T}}-$ коефіцієнт лінійного теплового розширення матеріалу; $\lambda$ та $\mu$ - коефіцієнт Ламе; $\mathrm{T}_{0}$ - початкова температура тіла.

Коефіцієнти $\lambda$ та $\mu$ пов'язані 3 технічними характеристиками матеріалу рівностями:

$\lambda=\frac{E v}{(1+v)(1-2 v)}, \quad \mu=\frac{E}{2(1+v)}$,

де $\mathrm{E}$ - модуль пружності (модуль Юнга), v - коефіцієнт Пуансона.

4) шість співвідношень між деформаціями та переміщеннями.

Коефіцієнт теплопровідності, питома теплоємність, густина, коефіцієнт лінійного теплового розширення та коефіцієнти Ламе матеріалу вважаємо неперервними функціями просторових координат. 


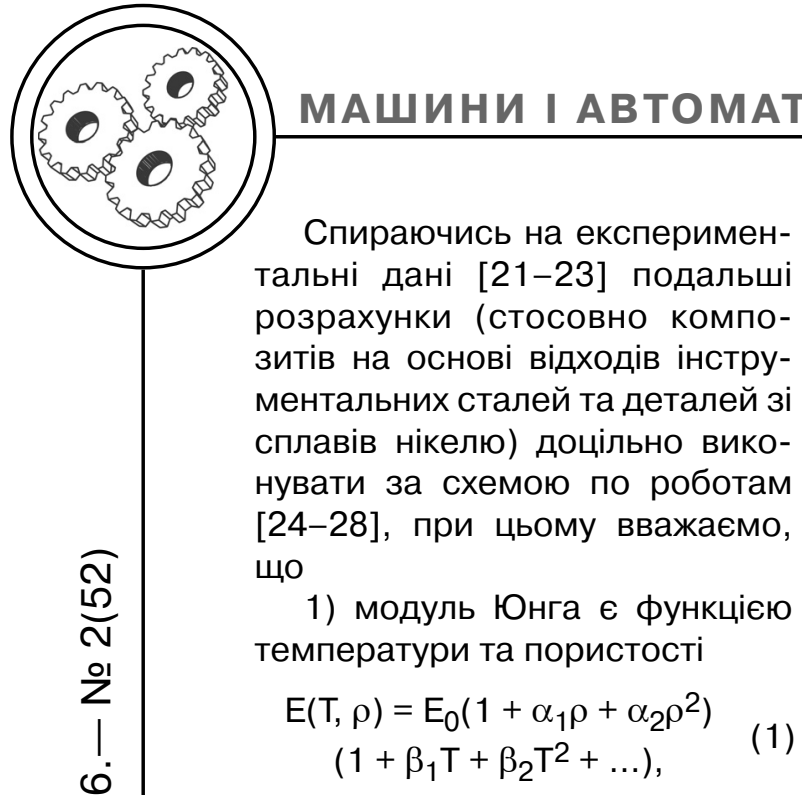

де $\alpha_{1}, \alpha_{2}, \beta_{1}, \beta_{2}$ - коефіцієнти, що отримані експериментальHO;

2) коефіцієнт теплопровідності матеріалу вважаємо залежним від температури та пористості [22, 23]:

$$
\begin{aligned}
& \lambda(T, \rho)=\lambda_{0} \sqrt{(1-\rho)^{3}} . \\
& \left(1+\beta_{1} T+\beta_{2} T^{2}+\ldots\right),
\end{aligned}
$$

де $\beta_{1}, \beta_{2}-$ емпіричні коефіцієнти. У наведеній формулі в основі лежить теплопровідність скелету пористого тіла. Власне пори у широкому діапазоні температур практично відсутні.

3) коефіцієнт лінійного розширення матеріалу $є$ функцією температури і не залежить від пористості. Основою для такого твердження $є$ той факт, що від теплової взаємодії розширюється скелетна частина матеріалу як суцільного тіла, величиною пор (порожнечі) при цьому нехтуємо. На основі експериментальних даних [21-23] отримуємо формулу $\alpha(T)=\alpha_{0}(1+$ $\left.+\alpha_{1} T+\alpha_{2} T^{2}+\ldots\right)$. При цьому середній коефіцієнт лінійного роз- ширення у робочому діапазоні температур:

$$
a_{c p}=\frac{1}{T-T_{0}} \int_{T_{0}}^{T} a(\tau) d \tau .
$$

4) у випадку внутрішнього тепловиділення для потужності теплового джерела приймемо залежність [21]:

$$
\begin{aligned}
W(T, P) & =W_{0}(1-P)\left(1+\gamma_{1} T+\right. \\
& \left.+\gamma_{1} T^{2}+\ldots\right) .
\end{aligned}
$$

Наближені гіпотези, що описують фізико-механічний стан матеріалу, дають можливість підходити до вирішення задач 3 позицій механіки неоднорідних матеріалів суцільних тіл, властивості яких корельовано на пористість.

Розглянемо задачу теплопровідності для порожнинного циліндру з радіально змінною пористістю. Тепловий режим приймаємо нестаціонарним. Розв'язок задачі теплопровідності зводиться до інтегрування нелінійного диференціального рівняння [21]:

$$
\begin{aligned}
& \frac{d}{d r}\left[\lambda(T, P) \frac{d T}{d r}\right]+ \\
& +\frac{\lambda(T, P)}{r} \frac{d T}{d r}+W(T, P)=0
\end{aligned}
$$

з граничними умовами

$$
\begin{aligned}
& T=T_{1} \text { при } r=R_{1} \\
& T=T_{2} \text { при } r=R_{2},
\end{aligned}
$$

де $\lambda(T, P)-$ коефіцієнт теплопровідності матеріалу як функція температури та пористості; $\mathrm{P}(\mathrm{r})$ - об'ємна пористість; $\mathrm{W}(T, \mathrm{P})$ - питома об'ємна потужність джерела тепла.

На основі експериментальних даних [21-23], апрокси- 
муємо $\lambda(T, P), W(T, P)$ функціями (2) та (4):

$$
\begin{gathered}
\lambda(T, P)=\lambda_{0} \sqrt{(1-\rho)^{3}} . \\
\cdot\left(1+\beta_{1} T+\beta_{2} T^{2}+\ldots\right), \\
W(T, P)=W_{0}(1-P)\left(1+\gamma_{1} T+\right. \\
\left.+\gamma_{2} T^{2}+\ldots\right) .
\end{gathered}
$$

Розв'язок нелінійного рівняння із змінними коефіцієнтами (5) будемо шукати по схемі методу послідовних наближень, вихідне рівняння до серії виду:

$\frac{\mathrm{d}}{\mathrm{dr}}\left[\lambda^{(\mathrm{m}-1)}(\mathrm{r}) \frac{\mathrm{dT} \mathrm{T}^{(\mathrm{m})}}{\mathrm{dr}}\right]+\frac{\lambda^{(\mathrm{m}-1)}(\mathrm{r})}{r} \frac{\mathrm{dT}^{(\mathrm{m})}}{\mathrm{dr}}+$ $+W\left[T^{(m-1)}, P\right]=0 \quad m=1,2,3 \&$

При $\mathrm{m}=1$ приймаємо $\quad \lambda^{0}(\mathrm{r})=$ $=\lambda_{0} \sqrt{(1-\rho)^{3}}$ та $\mathrm{W}^{(0)}(\mathrm{r})=\mathrm{W}_{0}(1-\mathrm{P})$.

При $\mathrm{m}>1$ отримаємо

$$
\begin{aligned}
\lambda(m)(r) & =\lambda(0)(r)\left[1+\beta_{1} T_{(m-1)}+\right. \\
& \left.+\beta_{2} T^{2}{ }_{(m-2)}+\ldots\right],
\end{aligned}
$$$$
W^{(m-1)}(r)=W^{(0)}(r)\left[1+\gamma_{1} T(m-1)\right.
$$$$
\left.+\gamma_{2} T_{(m-2)}^{2}+\ldots\right] \text {. }
$$

Розв'язок граничної задачі (6-7) замінимо еквівалентною варіаційною постановкою з пошуком мінімуму відповідного функціоналу:

$J_{(m)}=2 \pi \int_{R_{1}}^{R_{2}}\left\{\frac{\lambda^{(m-1)}(r)}{2}\left[\frac{d T_{m}}{d r}\right]^{2}-T_{m} W_{m-1}(r)\right\} r d r+$

$$
+\int_{S} W_{s} T_{m} d S+\int_{s} \frac{\alpha}{2}\left(T_{m}^{2}-2 T_{m} T_{m-1}+T_{m-1}^{2}\right) d S .
$$

Для реалізації мінімуму функціоналу (9) скористаємось методом скінченних елементів [25-28, 40].

Поділимо тіло по радіусу на $\mathrm{n}$ кільцевих елементів (рис. 1) та пронумеруємо їх границі і = 1, 2, $\ldots, \mathrm{n}+1$. Позначимо Ті шукану температуру в і-ому вузлі; відповідно отримаємо $\mathrm{T}=\mathrm{T}_{1}$ при $\mathrm{i}=1, \mathrm{~T}=\mathrm{T}_{2}$ при $\mathrm{i}=\mathrm{n}+1$. Розглянемо два суміжних елементи 1 та 2, що є спільними для вузла і та представимо функціонал $\mathrm{J}$ у вигляді суми $\mathrm{J}=\mathrm{J}_{1}+\mathrm{J}_{2}$, де отримаємо:

$J_{1}^{(m)}=\int_{r_{-1}}^{r}\left\{\frac{\lambda^{(m-1)}(r)}{2}\left[\frac{d T_{m}}{d r}\right]^{2}-T_{m} W^{(m-1)}(r)\right\} r d r+$ $+\int_{S} W_{s} T_{m} d S+\int_{s}^{\alpha} \frac{\alpha}{2}\left(T_{m}^{2}-2 T_{m} T_{m-1}+T_{m-1}^{2}\right) d S$ $J_{2}^{(m)}=\int_{r_{i}}^{r_{r+1}}\left\{\frac{\lambda^{(m-1)}(r)}{2}\left[\frac{d T_{m}}{d r}\right]^{2}-T_{m} w^{(m-1)}(r)\right\} r d r+$ $+\int_{S} W_{s} T_{m} d S+\int_{S} \frac{\alpha}{2}\left(T_{m}^{2}-2 T_{m} T_{m-1}+T_{m-1}^{2}\right) d S$.

Інші елементи можна не враховувати оскільки вони не містять вузол і. Множником $2 \pi$ l перед інтегралом нехтуємо.

Представимо функцію температури у кожному з елементів лінійним сплайном

$$
\begin{aligned}
\mathrm{T}_{(\mathrm{i}-1, j)} & =\mathrm{a}_{11}+\mathrm{a}_{12} \mathrm{r} \\
\mathrm{T}_{(\mathrm{i}, \mathrm{j}+1)} & =\mathrm{a}_{21}+\mathrm{a}_{22} \mathrm{r} .
\end{aligned}
$$

у останній системі коефіцієнти форми позначені через вузлові температури у вигляді:

$$
\begin{gathered}
a_{11}=T_{i-1}-\frac{r_{i-1}}{r_{i}-r_{i-1}}\left(T_{i}-T_{i-1}\right) ; \\
a_{12}=\frac{1}{r_{i}-r_{i-1}}\left(T_{i}-T_{i-1}\right) ; \\
a_{21}=T_{i}-\frac{r_{i}}{r_{i+1}-r_{i}}\left(T_{i+1}-T_{i}\right) ; \\
a_{22}=\frac{1}{r_{i+1}-r_{i}}\left(T_{i+1}-T_{i}\right) .
\end{gathered}
$$




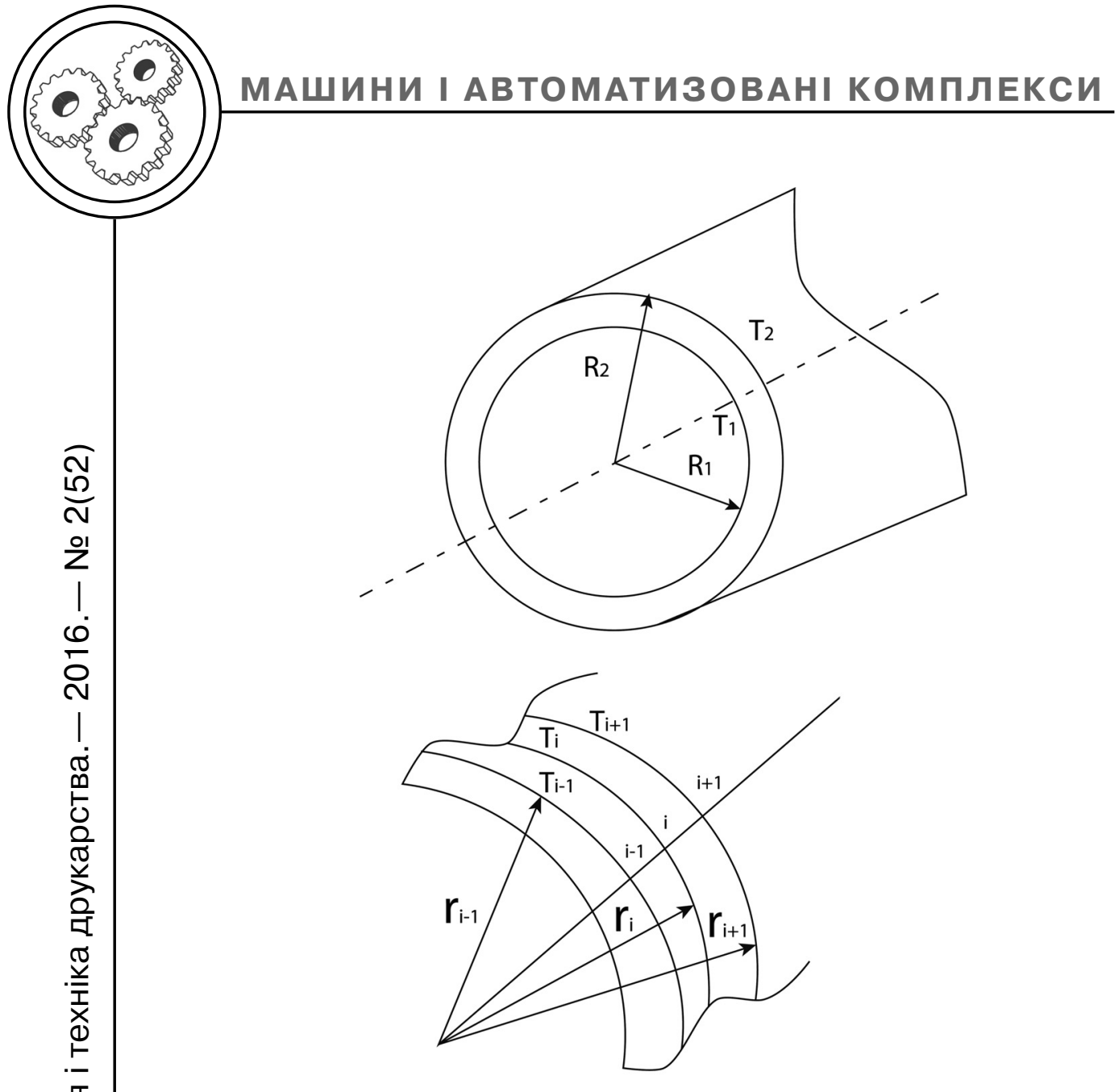

Рис. 1. Схема поділу втулки підшипника ковзання на скінченні елементи по радіусу

Представимо функціонали де було прийнято $\mathrm{J}_{1}^{(\mathrm{m})}, \mathrm{J}_{2}^{(\mathrm{m})}$ у вигляді:

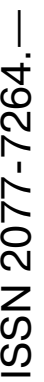

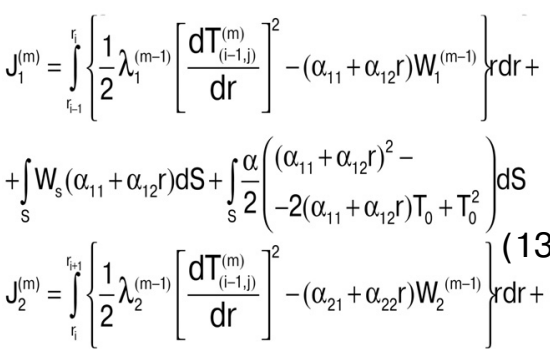
$\lambda_{1}^{(\mathrm{m}-1)}=\frac{\lambda_{i}^{(\mathrm{m}-1)}+\lambda_{i-1}^{(\mathrm{m}-1)}}{2}$, $W_{1}^{(m-1)}=\frac{W_{i}^{(m-1)}+W_{i-1}^{(m-1)}}{2}$.

Відповідно заміною індексів можна отримати $\lambda_{2}, W_{2}$.

Умовою екстремуму функціоналу J буде

$+\int_{S} W_{s}\left(\alpha_{21}+\alpha_{22} r\right) d S+$ $+\int_{S} \frac{\alpha}{2}\left(\begin{array}{l}\left(\alpha_{21}+\alpha_{22} r\right)^{2}-2\left(\alpha_{21}+\alpha_{22} r\right) \cdot \\ \cdot\left(\alpha_{11}+\alpha_{12} r\right)+\left(\alpha_{11}+\alpha_{12} r\right)^{2}\end{array}\right) d S$,

$$
\frac{\partial \mathrm{J}}{\partial T_{i}}=\frac{\partial \mathrm{J}_{1}}{\partial T_{i}}+\frac{\partial \mathrm{J}_{2}}{\partial T_{i}}=0 .
$$

Виконавши відповідні операції з функціоналами та на ос- 
нові (12-14) отримаємо алгебраїчну систему рівнянь відносно вузлових температур для m-ого наближення

$$
T_{i}^{(m)}=\frac{1}{A}\left[B_{i} T_{i+1}^{(m)}+C_{i} T_{i-1}^{(m)}+D_{i}\right],
$$

де позначено

$$
\begin{aligned}
& A_{i}=B_{i}+C_{i} ; \\
& B_{i}=\frac{\lambda_{1}^{(m-1)}}{2}\left[\frac{r_{i}+r_{i+1}}{r_{i+1}-r_{i}}\right] ; \\
& C_{i}=\frac{\lambda_{2}^{(m-1)}}{2}\left[\frac{r_{i-1}+r_{i}}{r_{i}-r_{i-1}}\right] \\
& D_{i}=-\frac{W_{1}^{(m-1)}}{6}\left[2 r_{i}^{2}-2 r_{i+1}^{2}-r_{i} r_{i+1}\right]- \\
& -\frac{W_{2}^{(m-1)}}{6}\left[r_{i} r_{i-1}+r_{i-1}^{2}-2 r_{i}^{2}\right] .
\end{aligned}
$$

При дослідженні тіл із зародками тріщин для врахування кореневої особливості при реалізації цієї схеми використовуються квадратичні сплакни і зміщення вузлів у скінченних елементів у вершині тріщин на четвертину довжини елемента [25-28]. Розглянемо типовий приклад, який час від часу має місце у ході виробництва поліграфічної техніки.

Тріщина у скінченній анізотропній пластині. Розглянемо анізотропну прямокутну пластинку 3 центральною тріщиною (рис. 2). Ширина пластинки W, a ії висота - 4W. Довжина тріщини - 2a, а кут її нахилу до осі Ох1 - $\gamma$. Пластинка виготовлена з композиту 11РЗАМЗФ2 на основі інструментальної сталі [1, 3] 3 такими властивостями: $\mathrm{E}_{11}=65$ гПа, $\mathrm{E}_{22}=31$ гПа, $v_{12}=0,21, \mathrm{G}_{12}=11,5$ гПа, $\mathrm{a}_{11}=$ $=7,5 \cdot 10^{-6} \mathrm{~K}^{-1}, \mathrm{a}_{22}=1,9 \cdot 10^{-5} \mathrm{~K}^{-1}$, $\mathrm{k}_{11} / \mathrm{k}_{22}=3,61 / 0,31$. Сторони AD та BC пластини теплоізольовані. Сторона $A B$ знаходиться при відліковій температурі $(\theta=0)$, а сторона DC охолоджна до температури $\theta_{0}$. Крім цього, сторони AB та DC шарнірно закріплені так, що кладові їхніх переміщень уздовж осі $O x_{2}$ дорівнюють нулю.

Результати розрахунку КIH у вершині $P$ та $Q$ тріщин, порівняно із даними роботи [9] подано в табл. 1. У таблиці використано такі позначення: ETM - це «exact transformation method» [9], за якого об'ємний інтеграл перетворюється до контурного у відображеній області; Sup. superposition approach [9], коли розв'язок отримують шляхом накладання полів теплових та пружних деформацій. Коефіцієнт нормування $\mathrm{K}_{0}=\mathrm{E}_{22} \mathrm{a}_{22} \theta_{0} \sqrt{\pi \mathrm{a}}$. При розбитті методом скінченних елементів використано

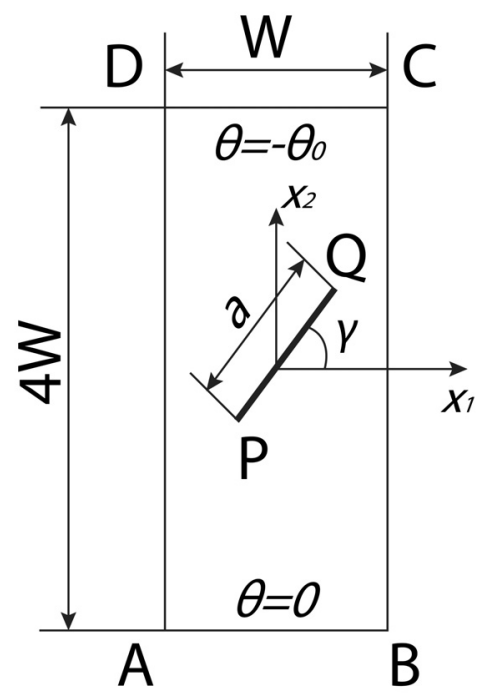

Рис. 2. Нахилена центральна тріщина в анізотропній прямокутній пластині 


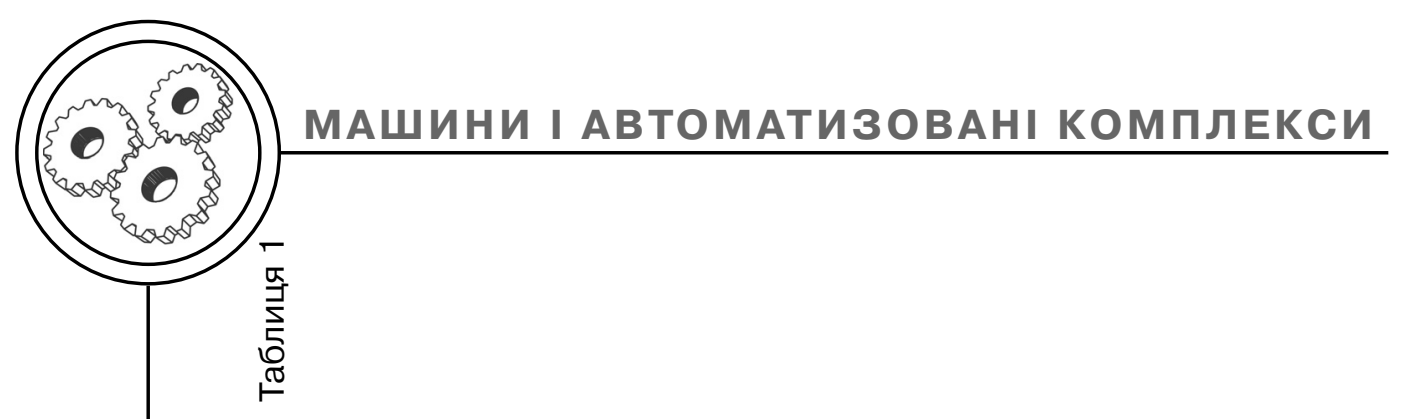

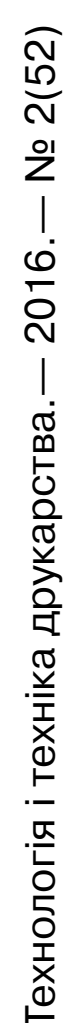

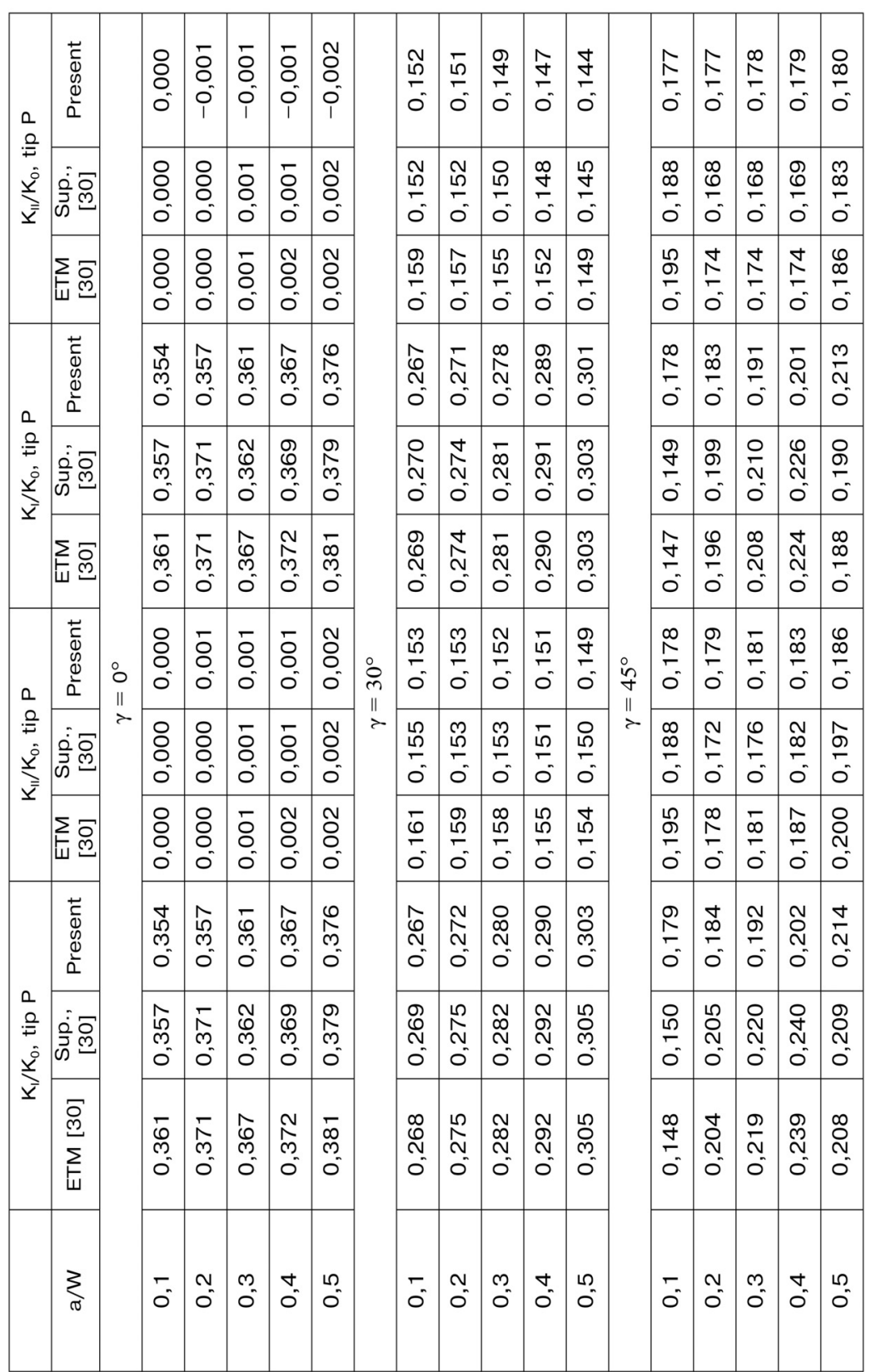


адаптивну сітку із 540 вузлами.

Табл. 1 засвідчує добру узгодженість результатів, отриманих запропонованим підходом, із даними [30]. При $\gamma=45^{\circ}$ отримано найбільшу розбіжність результатів, що можна пояснити використаною у роботі [30] технікою розбиття на підобласті, що породжує додаткові точки колокації на спільній межі підобластей, яка для кута $\gamma=45^{\circ}$ $\epsilon$ найбільшою серед усіх розглянутих. Крім цього, обчислені в [30] для $\gamma=45^{\circ} \mathrm{KIH} \mathrm{K}_{1}$ різко зростають при збільшенні відносної довжини тріщини а/W від 0,1 до 0,2 , а $\mathrm{KIH} \mathrm{K} \mathrm{K}_{11}$ для $\mathrm{a} / \mathrm{W}=0,1$ більший, ніж для $\mathrm{a} / \mathrm{W}=0,2$, а хоча у діапазоні a/W $=0,2 \ldots 0,5$ простежується їхнє монотонне зростання. 3 огляду на це, надійнішими видаються значення $\mathrm{KIH}$, обчислені запропонованим підходом.

Для ілюстрації інших можливих застосувань запропонованого підходу дослідимо нові задачі.

Розглянемо анізотропну квадратну пластинку з двома паралельними зародками тріщин. Розглянемо анізотропну пластинку зі скловолокна, що містить дві паралельні тріщини (рис. 3). На берегах тріщин відлікова (нульова) температура, а межа пластинки нагріта до температури $\theta_{0}$. Береги пластинки та тріщин вільні від від механічного навантаження. Отримані значення КІH у правій вершині нижньої тріщини залежно від довжин тріщин та відстаней між ними подано у табл. 2. Усі $\mathrm{KIH} \mathrm{нормовані} \mathrm{до} \mathrm{K}_{0}=\mathrm{E}_{22} \mathrm{a}_{22} \theta_{0} \sqrt{\pi \mathrm{a}}$.
Як і в ізотропному випадку тіла з однією тріщиною, домінуючим при температурних крайових умовах $€$ параметр $\mathrm{K}_{1}$. Проте, на відміну від пластинки з одною тріщиною, у випадку двох дефектів ненульовим $€$ також і параметр $\mathrm{K}_{11}$. Це зумовлено взаємодією тріщин. Проте $\mathrm{K}_{11}$ на порядок менший за $\mathrm{K}_{1}$, тому при розрахунку міцності таких пластинок ним можна знехтувати.

Із табл. 2 видно, що нормовані показники $\mathrm{K}_{1} / \mathrm{K}_{0}$ зменшуються зі збільшенням довжини тріщини та 3 віддаленням тріщин одна від одної (хоча сам показник KІ збільшується). У випадку довгих тріщин відстань між ними практично не впливає на $\mathrm{K}_{1}$, що зумовлено збільшенням впливу країв пластинки. За таких же довжин тріщин не простежується монотонної залежності $\mathrm{K}_{1}$ від відстані 2d між тріщинами. Максимуми $\mathrm{K}_{1}$ спостерігаються для $\mathrm{d} / \mathrm{W} \approx 0,2$.

\section{Висновки}

Узагальнюючи комплекс виконаних досліджень необхідно зробити наступні висновки.

1. Вперше у науковій практиці виконано теоретико-експериментальне дослідження температурного поля підшипників ковзання поліграфічних машин 3 вискозносостійких композитів на основі інструментальних сталей типу 7ХГ2ВМФ, 11РЗАМЗФ2, 5ХВЗМФС та відходів нікелевих сплавів ХН55ВМТКЮ і ХН50ВТФКЮ 3 аналізом формування напружень у поверхневих шарах дета- 


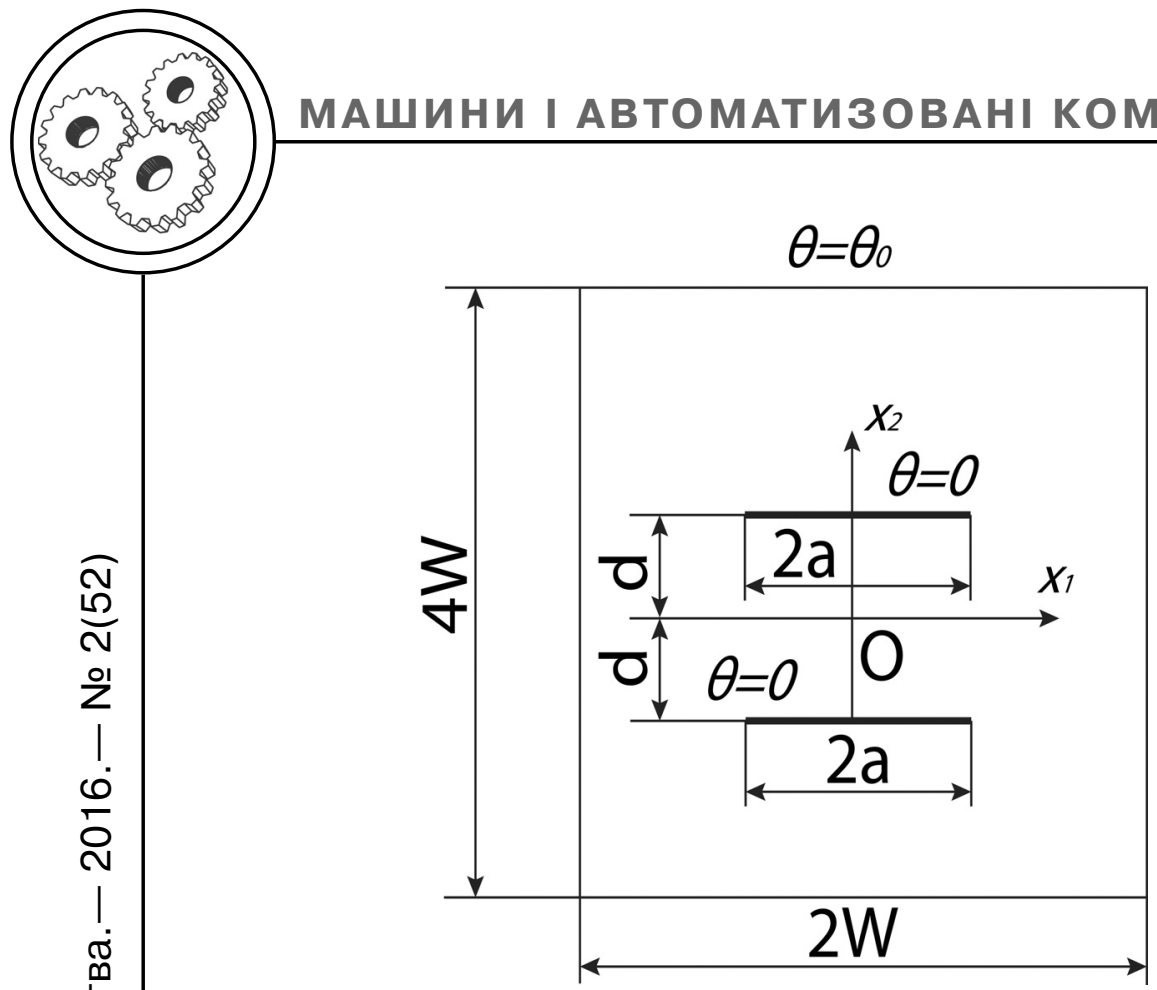

Рис. 3. Анізотропна пластинка з двома зародками тріщин

лей тертя за умов їх тонкого абразивного шліфування.

2. Запропонована методика та повний варіаційний функціонал можуть бути прийнятими за основу для розробки алгоритмів та схем наближеного розв'язування відповідних крайових задач з використанням варіаційних методів.

3. Отримані співвідношення варіаційного формування крайових задач $є$ вихідними для ітераційної побудови двомірних та

одномірних математичних моделей термомеханіки елементів конструкцій кілець композитних підшипників ковзання.

4. На підставі запропонованого функціоналу отримана схема методу скінченних елементів, яка виявила добру узгодженість результатів досліджень 3 відомими даними при вивченні структурно неоднорідних анізотропних тіл із тріщинами.

5. Подальші дослідження доцільно виконувати, вивчаючи ут-

Таблиця 2

Основні параметри зародків тріщини в анізотропній пластинці з двома тріщинами

\begin{tabular}{|c|c|c|c|c|c|c|c|c|c|c|c|}
\hline $\mathrm{d} / \mathrm{W}$ & 0,1 & 0,2 & 0,25 & 0,3 & 0,35 & 0,1 & 0,2 & 0,25 & 0,3 & 0,35 \\
\hline $\mathrm{a} / \mathrm{W}$ & \multicolumn{7}{|c|}{$\mathrm{K}_{\mathrm{K} / \mathrm{K}} / \mathrm{K}_{0}$} \\
\hline 0,1 & 0,175 & 0,183 & 0,177 & 0,170 & 0,162 & 0,001 & $-0,005$ & $-0,005$ & $-0,005$ & $-0,005$ \\
\hline 0,2 & 0,153 & 0,164 & 0,162 & 0,157 & 0,149 & 0,006 & $-0,005$ & $-0,008$ & $-0,008$ & $-0,008$ \\
\hline 0,3 & 0,142 & 0,153 & 0,151 & 0,147 & 0,141 & 0,007 & $-0,005$ & $-0,008$ & $-0,009$ & $-0,010$ \\
\hline 0,4 & 0,135 & 0,145 & 0,143 & 0,139 & 0,134 & 0,007 & $-0,006$ & $-0,009$ & $-0,010$ & $-0,010$ \\
\hline 0,5 & 0,130 & 0,137 & 0,136 & 0,133 & 0,129 & 0,005 & $-0,007$ & $-0,009$ & $-0,009$ & $-0,008$ \\
\hline 0,6 & 0,124 & 0,128 & 0,127 & 0,125 & 0,123 & 0,002 & $-0,009$ & $-0,009$ & $-0,007$ & $-0,006$ \\
\hline 0,7 & 0,116 & 0,117 & 0,116 & 0,116 & 0,115 & $-0,003$ & $-0,010$ & $-0,008$ & $-0,004$ & $-0,002$ \\
\hline
\end{tabular}


ворення теплових напружень у поверхневих шарах підшипників ковзання (для умов їх тонкого абразивного шліфування), щоб були виготовлені 3 найновітніших антифрикційних ма- теріалів - таких, як диборид титану, композитів типу сапоніт титану та сапоніт алюмінію, порошкових сплавів на основі гідриду титану та боридів цирконію.

\section{Список використаної літератури}

1. Роїк Т. А. Композиційні підшипникові матеріали для підвищених умов експлуатації : монографія / Т. А. Роїк, П. О. Киричок, А. П. Гавриш. - К. : НТУУ «КПІ», 2007. - 404 с.

2. Киричок П. О. Технологія поліграфічного машинобудування : навчальний посібник / П. О. Киричок, Т. А. Роїк, А. В. Шевчук, А. П. Гавриш, О. І. Лотоцька. - К. : НТУУ «КП|», 2014. - 504 с.

3. Роїк Т. А. Новітні композиційні матеріали деталей тертя поліграфічних машин : монографія / Т. А. Роїк, А. П. Гавриш, П. О. Киричок, Ю. Ю. Віцюк. К. : НТУУ «КПІ», 2014. - 427 с.

4. Киричок П. О. Фінішне оброблення зносостійких деталей друкарських машин : навч. посіб. / П. О. Киричок, Т. А. Роїк, А. П. Гавриш, А. В. Шевчук, Ю. Ю. Віцюк. - К. : НТУУ «КПІ», 2014. - 404 с.

5. Аскеров М. Г. Металлополимерные триботехнические материалы : монография / М. Г. Аскеров, Т. А. Роик, А. П. Гавриш. - К. : НТУУ «КПИ», 2015. $-218 \mathrm{c}$.

6. Гавриш О. А. Новітні технології виробництва стандартизованих виробів : монографія / О. А. Гавриш, Ю. Ю. Віцюк, Т. А. Роїк, А. П. Гавриш, С. В. Войтко. - К. : НТУУ «КПІ», 2012. - 204 с.

7. Роїк Т. А. Сучасні системи технологій заготівельного виробництва в машинобудуванні : монографія / Т. А. Роїк, А. П. Гавриш, О. А. Гавриш. - К. : Вид-во ЕКМО, 2010. - 210 с.

8. Костецкий Б. И. Износостойкость деталей машин / Б. И. Костецкий. - М. : Машиностроение, 1950. - 166 с.

9. Костецкий Б. И. Надежность и долговечность машин / Б. И. Костецкий, И. Г. Носовский, Л. И. Бершадский, А. К. Караулов. - К. : Техніка, 1975. $-408 \mathrm{c}$.

10. Костецкий Б. И. Основные вопросы теории трения и изнашивания деталей машин / Б. И. Костецкий. - М. : Машгиз, 1955. - 152 с.

11. Костецкий Б. И. Поверхностная прочность материалов при трении / Б. И. Костецкий, И. Г. Носовский, А. К. Караулов и др. - К. : Наукова думка, 1982. - 126 с.

12. Костецкий Б. И. Трение, смазка и износ в машинах / Б. И. Костецкий. - К. : Техника, 1970. - 396 с.

13. Крагельский И. В. Коэфициенты трения / И. В. Крагельский, И. Э. Виноградов. - М. : Машгиз, 1962. - 186 с.

14. Крагельский И. В. Основы расчетов на трение и износ / И. В. Крагельский, М. Н. Добычин, В. С. Комбалов. - М. : Машиностроение, 1977. - 526 с.

15. Крагельский И. В. Развитие науки о трении / И. В. Крагельский, В. С. Щедров. - М. : Изд-во АН СССР, 1956. - 235 с.

16. Крагельский И. В. Трение и износ / И. В. Крагельский. - М. : Машиностроение, 1968. - 478 с.

17. Крагельский И. В. Трение и износ в машинах / И. В. Крагельский. М. : Машгиз, 1962. - 284 с. 
18. Рыжов Э. В. Технологические методы повышения износостойкости деталей машин / Э. В. Рыжов. - К. : Наукова думка, 1984. - 340 с.

19. Рыжов Э. В. Контактная жесткость деталей машин : монография / Э. В. Рыжов. - К. : Наукова думка, 1987. - 320 с.

20. Гавриш А. П. Формування залишкових напружень під час шліфування композиційних матеріалів для поліграфічної техніки / А. П. Гавриш, Т. А. Роїк, А. П. Гавриш, О. І. Лотоцька, Ю. Ю. Віцюк // Вісник Житомирск. технологічн. ун-ту. -2014 . - № 3(70). - С. 17-26.

21. Беляев И. М. Проекционные и разностные методы в задачах теплообмена и термоупругости / И. М. Беляев, В. И. Завелион, А. А. Рядно. - Днепропетровск : Изд-во ДГУ, 1982. - 140 с.

22. Боли Б. Теория температурных напряжений / Б. Боли, Дж. Уэйнер. М. : Мир, 1964. - 517 с.

23. Био М. Вариационные принципы в теории теплообмена / М. Био. М. : Энергия, 1975. - 208 с.

24. Кошелюк В. А. Застосування MCE до розв'язування задач термопружності структурно-неоднорідних тіл / В. А. Кошелюк // Наукові нотатки. - Вид. ЛНТУ. 2015. - № 49. - С. 86-92.

25. Бронштейн И. Н., Семендяев К. А. Справочник по математике / под ред. Г. Гроше, В. Циглера; перевод с нем. - Лейпциг : Изд-во «Тойбнер»; М. : Главн. ред. фізико-матем. лит-ры, 1981. - 719 с.

26. Математическая энциклопедия. - М. : Советская энциклопедия. 1977. - Том 1. - 620 с.; Том 2, 1979. - 537 с.

27. Кудрявцев Л. Д. Математический анализ в двух томах / Л. Д. Кудрявцев. - М. : Высшая школа, 1980. - 435 с.

28. Владимиров В. С. Уравнения математической физики / В. С. Владимиров. - М. : Наука, 1976. - 520 с.

29. Pan E. A general boundary element analisis of $2 \mathrm{D}$ linear elastic fracture mechanics // Int. I. Fract. - 1977. - № 88. - P. 41-59.

30. Shiah Y. C. Fracture mechanics in 2-D anisotropic thermoelasticity using BEM / Y. C. Shian, C. L. Tan. - CMES. - 2000. - Vol. 1. - № 3. - P. 9199.

31. Sollero P. Anisotropic analysis of craks in composite laminates using the dual boundary element method / P. Sollero, M. H. Alibadi // Composite structures. - 1995. - № 31. - P. 229-233.

32. Гавриш А. П. Фінішна алмазно-абразивна обробка магнітних матеріалів : монографія / А. П. Гавриш, П. П. Мельничук. - Житомир : Вид-во Житомирськ. державн. технологічн. ун-ту (ЖДТУ), 2004. - 551 с.

33. Маслов Е. Н. Теория шлифования материалов / Е. Н. Маслов. - М. : Машиностроение, 1974. - 320 с.

34. Ящерицын П. И. Прогрессивная технология финишной обработки деталей / П. И. Ящерицын. - Минск : Беларусь, 1989. - 312 с.

35. Новиков Н. В. Инструменты из сверхтвердых материалов / под ред. акад. НАН Украины Н. В. Новикова, д.т.н. С. А. Клименко. - М. : Машиностроение, 2014. - 607 с.

36. Лаврименко В. І. Надтверді абразивні матеріали в механообробці : Енциклопедичний довідник під заг. ред. акад. НАН України М. В. Новікова. - К. : Вид-во ІНМ НАН України, 2013 - 456 с.

37. Основи теорії різання матеріалів : підручник / М. П. Мазур, Ю. М. Внуков, В. Л. Добросюк, В. М. Залога, Ю. М. Новосьолов, Ф. Я. Якубов; під заг. ред. М. П. Мазура. - Львів : Новий світ, 2010. - 423 с. 38. Сверхтвердые материалы. Получение и применение : монографія в 6 т. / под общ. ред. акад. Новикова Н. В. - К. : ИСМ им В. Н. Бакуля НАНУ, 
2007. - т. 6 : Алмазно-абразивный инструмент / под ред. А. А. Шепелева. $-340 \mathrm{c}$.

39. Эльбор в машиностроении : монография (В. С. Лысанов, В. А. Букин, Б. А. Глаговский, З. И. Кремень и др.; под. общ. ред. В. С. Лысанова. Л-д. : Машиностроение, 1978. - 280 с.

40. Сегерлинд Ларри Дж. Применение метода конечных элементов / под. ред. Б. Е. Победри. - М. : Мир, 1979. - 392 с.

\section{References}

1. Roik, T. A. \& Kyrychok, P. O. \& Havrysh A. P. (2007). Kompozytsiini pidshypnykovi materialy dlia pidvyshchenykh umov ekspluatatsii [Composite bearing materials for elevated operating conditions]. Kyiv: NTUU 'KPI' [in Ukrainian].

2. Kyrychok, P. O. \& Roik, T. A. \& Shevchuk, A. V. \& Havrysh, A. P. \& Lototska, O. I. (2014). Tekhnolohiia polihrafichnoho mashynobuduvannia [Technology of printing machinery]. Kyiv: NTUU 'KPI' [in Ukrainian].

3. Roik, T. A. \& Havrysh, A. P. \& Kyrychok, P. O. \& Vitsiuk, lu. Iu. (2014). Novitni kompozytsiini materialy detalei tertia polihrafichnykh mashyn [The latest composite materials of the friction pieces for printing machines]. Kyiv: NTUU 'KPI' [in Ukrainian].

4. Kyrychok, P. O. \& Roik, T. A. \& Havrysh, A. P. \& Shevchuk, A. V. \& Vitsiuk, lu. lu. (2014). Finishne obroblennia znosostiikykh detalei drukarskykh mashyn [Finish machining of wear parts of printing machines]. Kyiv: NTUU 'KPI' [in Ukrainian].

5. Askerov, M. G. \& Roik, T. A. \& Gavrish, A. P. (2015). Metallopolimernye tribotehnicheskie materialy [Metal-polymer tribological materials]. Kiev: NTUU 'KPI' [in Russian].

6. Havrysh, O. A. \& Vitsiuk, lu. lu. \& Roik, T. A. \& Havrysh, A. P. \& Voitko, S. V. (2012). Novitni tekhnolohii vyrobnytstva standartyzovanykh vyrobiv [The latest technology of production of standardized products]. Kyiv: NTUU 'KPI' [in Ukrainian].

7. Roik, T. A. \& Havrysh, A. P. \& Havrysh, O. A. (2010). Suchasni systemy tekhnolohii zahotivelnoho vyrobnytstva $v$ mashynobuduvanni [Modern systems blanking production technologies in mechanical engineering]. Kyiv: Vyd-vo EKMO [in Ukrainian].

8. Kosteckij, B. I. (1950). Iznosostojkost' detalej mashin [The wear resistance of machine parts]. Moscow: Mashinostroenie [in Russian].

9. Kosteckij, B. I. \& Nosovskij, I. G. \& Bershadskij, L. I. \& Karaulov, A. K. (1975). Nadezhnost' i dolgovechnost' mashin [The reliability and durability of machines]. Kiev: Tekhnika [in Russian].

10. Kosteckij, B. I. (1955). Osnovnye voprosy teorii trenija i iznashivanija detalej mashin [Main questions of the theory of friction and wear of machine parts]. Moscow: Mashgiz [in Russian].

11. Kosteckij, B. I. \& Nosovskij, I. G. \& Karaulov, A. K. \& other (1982). Poverhnostnaja prochnost' materialov pri trenii [Surface strength of materials during friction]. Kiev: Naukova dumka [in Russian].

12. Kosteckij, B. I. (1970). Trenie, smazka $i$ iznos v mashinah [Friction, lubrication and wear in machines]. Kiev: Tehnika [in Russian].

13. Kragel'skij, I. V. \& Vinogradov, I. Je. (1962). Kojeficienty trenija [The coefficient of friction]. Moscow: Mashgiz [in Russian].

14. Kragel'skij, I. V. \& Dobychin, M. N. \& Kombalov, V. S. (1977). Osnovy raschetov na trenie $i$ iznos [Fundamentals of calculations on friction and wear]. Moscow: Mashinostroenie [in Russian]. 
15. Kragel'skij, I. V. \& Shhedrov, V. S. (1956). Razvitie nauki o trenii [The development of the science of friction]. Moscow: Izd-vo AN SSSR [in Russian].

16. Kragel'skij, I. V. (1968). Trenie i iznos [Friction and wear]. Moscow: Mashinostroenie [in Russian].

17. Kragel'skij, I. V. (1962). Trenie $i$ iznos $v$ mashinah [Friction and wear in machines]. Moscow: Mashgiz [in Russian].

18. Ryzhov, Je. V. (1984). Tehnologicheskie metody povyshenija iznosostojkosti detalej mashin [Technological methods to improve the wear resistance of machine parts]. Kiev: Naukova dumka [in Russian].

19. Ryzhov, Je. V. (1987). Kontaktnaja zhestkost' detalej mashin [Contact rigidity of machine parts]. Kiev: Naukova dumka [in Russian].

20. Havrysh, A. P. \& Roik, T. A. \& Havrysh, A. P. \& Lototska, O. I. \& Vitsiuk, lu. lu. (2014). Formuvannia zalyshkovykh napruzhen pid chas shlifuvannia kompozytsiinykh materialiv dlia polihrafichnoi tekhniky [The formation of residual stresses in grinding of composite materials for polygraphic equipment]. Journal of Visnyk Zhytomyrsk. tekhnolohichn. un-tu - The Bulletin of Zhytomyr Technological University, 3(70), 17-26 [in Ukrainian].

21. Beljaev, I. M. \& Zavelion, V. I. \& Rjadno A. A. (1982). Proekcionnye $i$ raznostnye metody $v$ zadachah teploobmena i termouprugosti [Projection and difference methods in problems of heat transfer and thermoelasticity]. Dnepropetrovsk: Izd-vo DGU [in Russian].

22. Boli, B. \& Ujejner Dzh. (1964). Teorija temperaturnih naprjazhenij [Theory of thermal stresses]. Moscow: Mir [in Russian].

23. Bio, M. (1975). Variacionnye principy $v$ teorii teploobmena [Variational principles in the theory of heat transfer]. Moscow: Jenergija [in Russian].

24. Kosheliuk, V. A. (2015). Zastosuvannia MSE do rozv'iazuvannia zadach termopruzhnosti strukturno-neodnoridnykh til [The use of the MSE to the solution of problems of thermoelasticity of structurally inhomogeneous bodies]. Journal of Naukovi notatky - Scientific Notes, 49, 86-92 [in Ukrainian].

25. Bronshtejn, I. N. \& Semendjaev, K. A. (1981). Spravochnik po matematike [Handbook of mathematics]. Lejpcig: Izd-vo 'Tojbner'; Moscow: Glavn. red. fiziko-matem. lit-ry [in Russian].

26. (1977, V. 1), (1979, V. 2). Matematicheskaja jenciklopedija [Mathematical encyclopedia]. Moscow: Sovetskaja jenciklopedija [in Russian].

27. Kudrjavcev, L. D. (1980). Matematicheskij analiz $v$ dvuh tomah [Mathematical analysis in two volumes]. Moscow: Vysshaja shkola [in Russian].

28. Vladimirov, V. S. (1976). Uravnenija matematicheskoj fiziki [Equations of mathematical physics]. Moscow: Nauka [in Russian].

29. Pan, E. (1977). A general boundary element analisis of 2D linear elastic fracture mechanics. Int. I. Fract, 88, 41-59 [in English].

30. Shiah, Y. C. \& Tan, C. L. (2000). Fracture mechanics in 2-D anisotropic thermoelasticity using BEM, Vol. 1, 3, 91-99 [in English].

31. Sollero, P. \& Alibadi, M. H. (1995). Anisotropic analysis of craks in composite laminates using the dual boundary element method. Journal of Composite Structures, 31, 229-233 [in English].

32. Havrysh, A. P. \& Melnychuk, P. P. (2004). Finishna almazno-abrazyvna obrobka mahnitnykh materialiv [Finish diamond-abrasive treatment of magnetic materials]. Zhytomyr: Vyd-vo Zhytomyrsk. derzhavn. tekhnolohichn. un-tu (ZhDTU) [in Ukrainian].

33. Maslov, E. N. (1974). Teorija shlifovanija materialov [Theory of grinding of materials]. Moscow: Mashinostroenie [in Russian]. 
34. Jashhericyn, P. I. (1989). Progressivnaja tehnologija finishnoj obrabotki detalej [An advanced technology of finishing of parts]. Minsk: Belarus' [in Russian].

35. Novikov, N. V. (2014). Instrumenty iz sverhtverdyh materialov [Tools of superhard materials]. Moscow: Mashinostroenie [in Russian].

36. Lavrymenko, V. I. (2013). Nadtverdi abrazyvni materialy v mekhanoobrobtsi [Superhard abrasive materials in the mechanical-processing]. Kyiv: Vyd-vo INM NAN Ukrainy [in Ukrainian].

37. Mazur, M. P. \& Vnukov, lu. M. \& Dobrosiuk, V. L. \& Zaloha, V. M. \& Novosolov, lu. M. \& Yakubov, F. la. (2010). Osnovy teorii rizannia materialiv [Fundamentals of the theory of cutting of materials]. Lviv: Novyi svit [in Ukrainian].

38. (2007). Sverhtverdye materialy. Poluchenie i primenenie. t. 6: Almaznoabrazivnyj instrument [Superhard materials. Obtaining and deploying. Vol. 6 Diamond-abrasive tool]. Kiev: ISM im V. N. Bakulja NANU [in Russian].

39. Lysanov, V. S. \& Bukin, V. A. \& Glagovskij, B. A. \& Kremen', Z. I. \& other (1978). Jel'bor $v$ mashinostroenii [Elbor in machine building]. Leningrad: Mashinostroenie [in Russian].

40. Segerlind, Larri Dzh. (1979). Primenenie metoda konechnih jelementov [Application of the finite element method]. Moscow: Mir [in Russian].

В статье представлены результаты теоретико-експериментального исследования температурного поля подшипников скольжения полиграфических машин из новых высокоизносостойких композитных материалов, синтезированных на основе использования утилизированных и регенерированных отходов производства деталей из инструментальных сталей и никеля типа 11РЗАМЗФ2, 7ХГ2ВМФ, 5ХВЗМФС, ХН55ВМТКЮ, ХН50ВТФКЮ, и его влияния на формирование остаточных напряжений в поверхностном слое композитной детали для условий тонкого абразивного шлифования. Предложен численно-аналитический метод решения задач термоупругости и определения температурного поля структурно-неоднородного тела для случая стабильности силовых параметров резания в зоне формирования напряжений при прецизионном тонком абразивном шлифовании. Предложенный метод базируется на методе конечных элементов решения задач термоупругости. Получены зависимости для определения температурного поля и приведены численне примеры их решения для реальных условий производства. Разработаны практические рекомендации по режимам резания при тонком шлифовании и выбору параметров абразивных инструментов для промышленности при производстве полиграфических машин.

Ключевые слова: высокоизносостойкие композиционные материалы; тонкое абразивное шлифование; параметры качества поверхности; температурное поле зоны резания; термоупругость; структурно-неоднородное тело; 


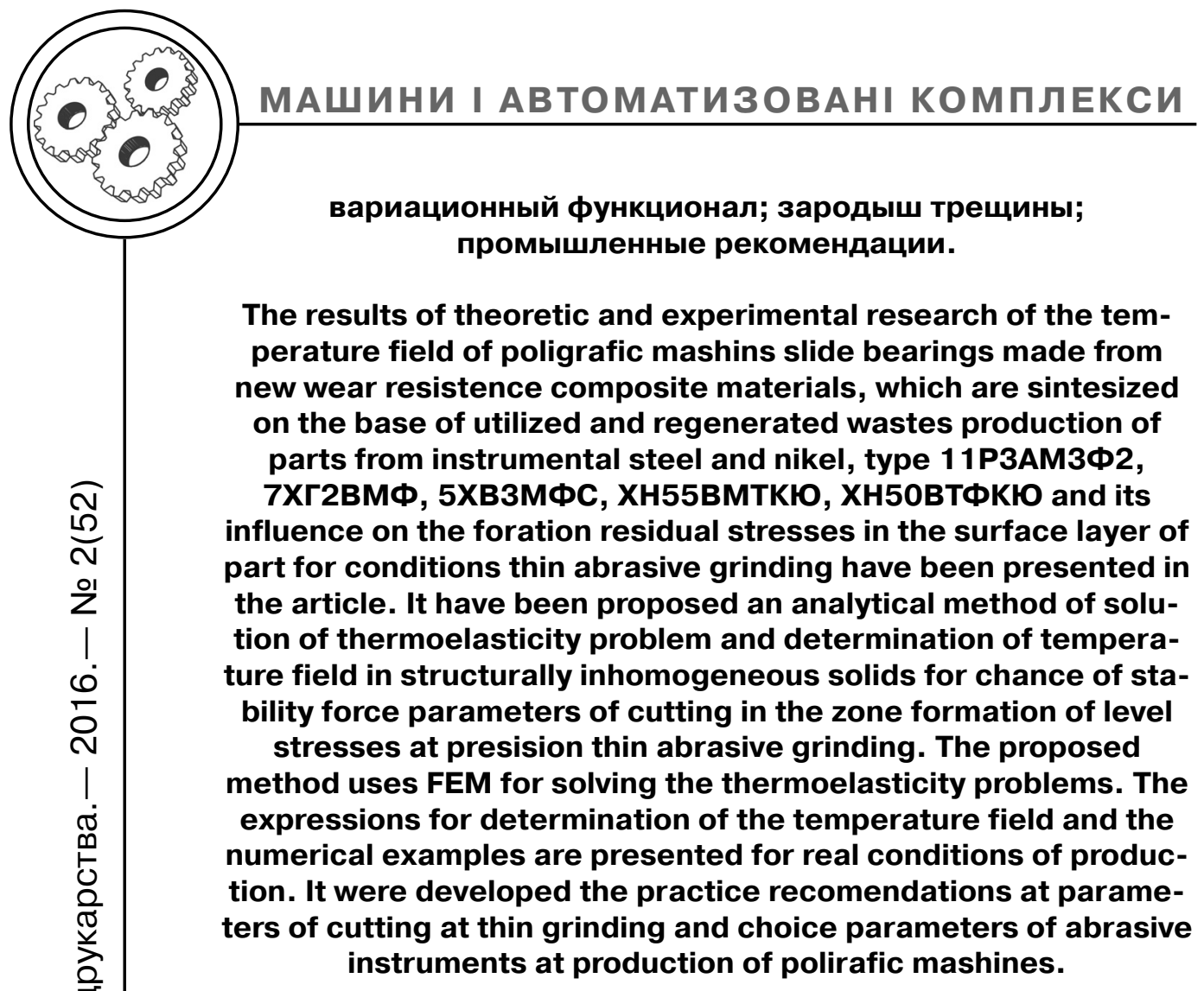

Keywords: wear resistance composite materials; thin abrasive grinding; parameters quality of surface; temperature field of zone cutting; thermoelasticity; structurally inhomogeneous solids; variation functional; nucleation of crack; industrial recomendations.

Рецензент - О. М. Величко, д.т.н., с.н.с., професор, НТУУ «КПI»

Надійшла до редакції 22.09.15 